\title{
Constructing Model of Influence of Cooperative Atmosphere, Work Motivation and Leadership Style on Job Satisfaction: A Survey in Indonesia
}

Muhammad Hussin, Faridah Karim, Henry Mappesona, Ricardo. S. P. M. M.

To Link this Article: http://dx.doi.org/10.6007/IJARBSS/v11-i3/8962 DOI:10.6007/IJARBSS/v11-i3/8962

Received: 01 January 2021, Revised: 30 January 2021, Accepted: 19 February 2021

Published Online: 15 March 2021

In-Text Citation: (Hussin et al., 2021)

To Cite this Article: Hussin, M., Karim, F., Mappesona, H., \& M., R. S. P. M. (2021). Constructing Model of Influence of Cooperative Atmosphere, Work Motivation and Leadership Style on Job Satisfaction: A Survey in Indonesia. International Journal of Academic Research in Business and Social Sciences, 11(3), 511-521.

Copyright: (c) 2021 The Author(s)

Published by Human Resource Management Academic Research Society (www.hrmars.com) This article is published under the Creative Commons Attribution (CC BY 4.0) license. Anyone may reproduce, distribute, translate and create derivative works of this article (for both commercial and non-commercial purposes), subject to full attribution to the original publication and authors. The full terms of this license may be seen at: http://creativecommons.org/licences/by/4.0/legalcode

Vol. 11, No. 3, 2021, Pg. 511 - 521

Full Terms \& Conditions of access and use can be found at http://hrmars.com/index.php/pages/detail/publication-ethics 


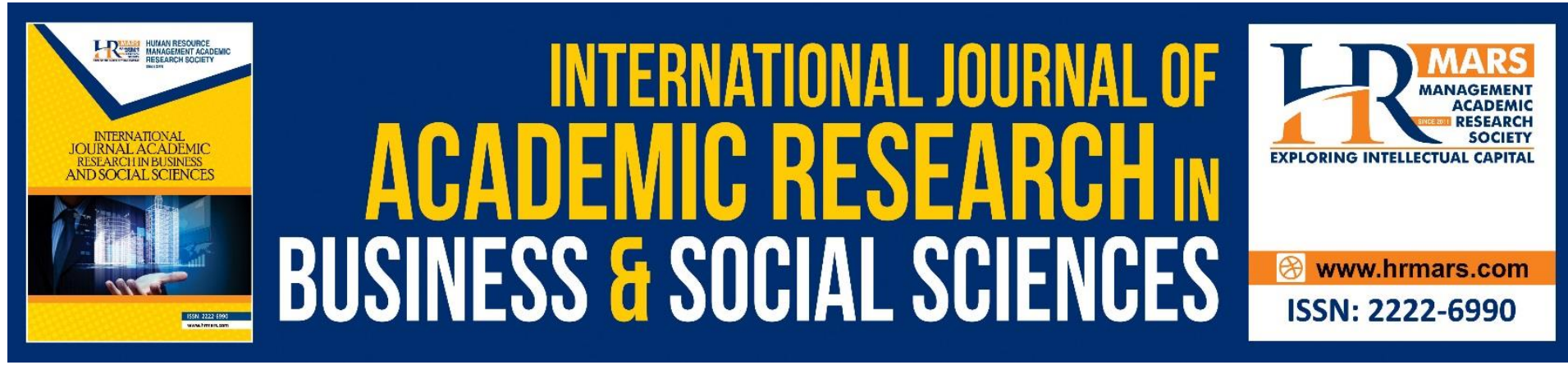

\title{
Constructing Model of Influence of Cooperative Atmosphere, Work Motivation and Leadership Style on Job Satisfaction: A Survey in Indonesia
}

\author{
Muhammad Hussin, Faridah Karim \\ Faculty of Education, Universiti Kebangsaan Malaysia, 43600 Bangi, Malaysia. \\ Email: freeuniversity@outlook.com,muhsin@ukm.edu.my \\ Henry Mappesona \\ Universitas Ekasakti-AAI Padang Sumatra Barat, Indonesia \\ Email:mappesona@gmail.com \\ Ricardo. S. P. M. M. \\ Universitas Ekasakti-AAI Padang Sumatra Barat, Indonesia \\ Email: ricardo2543@yahoo.co.id
}

\begin{abstract}
This study is to explore the influence of cooperative atmosphere, work motivation and leadership style of principals on teacher job satisfaction. The survey will enable a route analysis or path analysis to be performed to develop influence models on factors regarding cooperative atmosphere, work motivation and leadership style on job satisfaction. This study is important because some view shows that there is a decline in the Indonesian education system in producing quality work force despite the Indonesian government's efforts to improve the well-being of teachers through improving the service scheme. The result shows that in terms of gender, age, education and length of service, that teachers have created a very good atmosphere of cooperation between teachers and between teachers and principals. The findings also found that other factors such as work motivation, initiating structure-oriented leadership style and consideration-oriented leadership style (consideration) were identified to influence, contribute and determine and improve the level of teachers' job satisfaction whether separately or even in combination (together).
\end{abstract}

Keywords: Cooperative Atmosphere, Work Motivation, Leadership Style, Job Satisfaction, Indonesia.

\section{Introduction}

In an effort to improve the scheme of service for teachers, the Indonesian government had created opportunities for diploma teachers to pursue their studies to the degree level. However, as stressed by Mulyasa (2002), this effort does not yield much positive impact on 
the development of human resources in Indonesia. These conditions raised the concern of the education sector in Indonesia as clearly illustrated through large scale demonstrations by the teachers included in the news released by the Independent News dated on October 5 , 2000. This demonstration gives a clear picture on the teachers concern regarding their service to the education sector particularly with regards to payment of wages.

Although there are concerns over the education services benefits, however some studies suggest that in addition to salary, teacher dissatisfaction also depends on other influences such as the cooperative atmosphere in the organization, motivational factors as well as the organizations' leadership style (Sin, 2001). Even Waller (1965) states that working as a teacher is considered one of the most dissatisfied profession in the education line of work.

Locke (1976) also concluded that studies on job satisfaction is becoming more vital for job satisfaction affect work absence, quitting, delay, groaning, coming late and leaving the office quickly. Further study by Locke and Latham (1990) stated that job satisfaction is an important variable in an organization, because employees with high job satisfaction tend to continue in the interest of the organization and tend to help its partners in the organization as well.

Studies by Sin (2001) showed that job satisfaction is influenced by cooperative atmosphere. Cooperative atmosphere is found within the organization's atmosphere created by patterns of relationships among individuals within the organization. Cooperative atmosphere is an important component of the extrinsic factors that influence job satisfaction. Collaboration between teachers and principals will create job satisfaction, because this cooperation will enable them to overcome difficulties faced at work by working together (Andrews \& Morefield, 1991).

In addition to the cooperation atmosphere, motivational factor is also very important for explaining why workers perform their jobs (Jennifer \& Gareth, 1999). What becomes the main strength of motivation is necessity (need) according to Maslow's hierarchy of needs (Maslow, 1987) which refer to the five levels of needs starting with the lowest physiological need, safety need, social need, egoistic need and self-actualization need. Maslow further explained that when individuals and organizations grow, individual necessity change. In each individual, certain physiological need is necessary to be executed before the higher-level need. In other words, a need a for higher necessity will not be needed when the lower necessity has not been met.

Atmosphere of cooperation and work motivation will exist depending on the style of the leadership. As leaders, they must understand the importance of teamwork. Those who are effective in leadership are those who have successfully deploy their followers to work. On this matter as reported by Winardi (1989) shows that leadership is an activity to influence people to work with allure in order to achieve its intended purpose. Therefore, it is assumed that there is a positive relationship between the atmosphere of cooperation, work motivation, job satisfaction and leadership style (Kim, 1986).

\section{Purpose of Study}

The purpose of this study was to explore the relationship between of cooperative atmosphere, work motivation, and leadership style on teacher job satisfaction for the construction of model influence on job satisfaction. Specifically, the objective of the study is as follow: 
- to determine the factors influencing cooperative atmosphere, motivation and preferences on work-oriented leadership style structure and orientation consideration of job satisfaction,

- this study also aimed to develop a model of influence of factors cooperative atmosphere, motivation and work-oriented leadership style (initiating structure and orientation consideration) on job satisfaction.

\section{Method of Study}

Data collection was done by conducting a survey of secondary school teachers throughout Secondary School in the town of Padang. Population and sampling technique used is the stratified sampling technique where in each school the teachers were randomly selected and will be included in the sample, the instrument, a pilot study and data collection procedures.

The research framework is divided into two parts, namely the independent variable (independent) and the dependent variable (dependent). The independent variables consist of the cooperative atmosphere (X1), work motivation (X2) and principal's leadership style (X3). While the dependent variable consists of the teacher job satisfaction (Y).

Sample in this study consists of teachers who have been appointed as Civil Affairs Officer at Sekolah Lanjutan Tingkat Pertama (SLTP) throughout the Municipality of Padang, West Sumatra Province, Indonesia. There are several reasons associated with this sample selection. They cover the entire study population of teachers serving as Civil Affairs Officer at Sekolah Lanjutan Tingkat Pertama (SLTP) in Kota Padang, which amounted to a total of 1829 teachers from 34 schools.

Sampling technique is done by using a disproportionately Stratified Random Sampling method, which will produce the sample in proportion to the population of each stratum group. Usage of Stratified random sampling was proportional for teachers in the city of Padang SLTP and it is very heterogeneous whether at education level, work experience, gender, and marital status and while the number of teachers is not the same for each stratum, the number of male teachers and girls are also not the same and work experience / work time also vary greatly. Usage of this sampling is expected enough to represent the population.

Stratification in this study is determined based on education level, gender, age, marital status, and length of service. Respondents' education level is split between a master's degree and diploma. For gender it consists of male and female. While working time is based on work experience ranging 0-5 years, 6-10 years and $11-38$ years. The teachers age consists of 25 years old up to 36 years old, 37 years old up to 48 years old, and 49 years old up to 60 years old. The status is made up of married, unmarried and divorce. Next given the number of respondents for each stratum are not the same, in order to get enough samples representing the population, the selection is done in proportion of respondents in each stratum, using a random number table (Hair et al., 2006).

As pointed out earlier that the goal of study in this thesis is to investigate the influence of cooperation atmosphere, work motivation and leadership styles of school principals on teacher job satisfaction. In general, this study is a quantitative study. Therefore, a way to collect data is needed until a conclusion could be drawn based on the available data.

Questionnaire to measure cooperative atmosphere were developed by the researchers based on the commitment to the organization of the teachers and follow the guidelines of instrument development (Sudman \& Bradburn, 1973), Organizational Commitment by Cook et al. (1981), and a part from a cluster questionnaire survey with a standard score instrument that was expanded from the institute on Social Research at the 
University of Michigan. This questionnaire was modified by the researcher based on indicator or variables on similar work on cooperative atmosphere that were listed.

With regards to the questionnaire on work motivation, the researcher uses questionnaire from the Job Diagnostic Survey: Internal Work Motivation (Hackman \& Oldham, 1975). Intrinsic Job Motivation from Warr et al. (1978), A Measure of Questionnaire Individual Differences in Achieving Tendency (QMAT) of messaging designed by Mehrabian and Bank (1978), translated by researchers and modified based on indicators (characteristics). Questionnaire on leadership style variables is built from Behavior Description Questionnaire (LBDQ form XII), which was designed by the Personnel Research Board (personal Research Board) Ohio State University in which it will be answered by the teacher. Questionnaire based on LBDQ stems from two types of behaviour from the principals which were based on structured task (initiating structure) and consideration. This questionnaire has been used by many researchers among others including Ba'ada (2001), Sin (2001), and Hisham (2014) to study the relationship between the leadership style in the school atmosphere and student achievement as the basis for principal leadership.

Questionnaire to measure satisfaction was measured using a Job Description Index (JDI), which was developed by Smith et al. (1975). Smith et al. (1975) and then modified in turn by Konting (2000) for use by researchers. JDI measurement tool provides a number of advantages. JDI validity has been widely supported by previous studies, Vroom (1964) considers the JDI as something that has been meticulously designed to measure job satisfaction that exists at the present time. Smith et al. (1975) and Yeager (1981) also stated that JDI is an instrument often used in measuring job satisfaction. This measuring instrument has a high level of validity when compared with other methods of work measurement. However, researchers still conduct a pilot test with prior scrutiny in relation to the location that concerns the local culture.

In this study, multiple regression model is used to predict the relationship and interaction of variables associated with the independent variable including that of cooperative atmosphere, work motivation and leadership style. The $F$ value from regression ANOVA table is used to test whether a relationship exists between the dependent variable $(Y)$ and the independent variables (X1, X2, and X3) can be significant or otherwise. Pedhazur (1982) techniques of step by step (Stepwise) was used to obtain the contribution R (percent) for each independent variable. Further analysis using PLSGRAPH computer Version 2. were used to investigate the relationship between variables.

Before the multiple regression analysis, the researcher first ensures and verify whether the distribution of the questionnaire score and linear normal or otherwise. This is done by means of graph plots the distribution (residue / scatter plot) and normal plot of regression can be obtained from the sub-programs 'Linear Regression: Plots' available in SPSS. This step is important because multiple regression analysis assumes that the distribution of scores is normal and linear.

\section{Findings and Discussion Cooperative Atmosphere}

According to the respondents as a whole is found both in terms of gender, age, education and in terms of length of service, that teachers have created a very good atmosphere of cooperation between teachers and between teachers and principals, because teachers would appreciate the opinion of others, with high attitude of openness, and created an atmosphere of mutual trust and friendly camaraderie. From the mean calculation based on the total 
sample of 312 people, data shows that the quality of collaborative climate is high at mean score of 4.06 based on 5 score of Likert scale (Likert, 1961). This means that teachers realize the need for cooperation in carrying out their duties to achieve the effectiveness of teaching and school effectiveness in realizing its vision and mission. The findings of this study support the opinion Waller (1965) that teachers need good social relations, between the components present in the school, if the teacher does not create a good social relationship, these teachers will be left behind on the progress in the field of education.

However, if viewed in detail, it was found that within establishing cooperation, higher mean scores were from female teachers, and teachers who are 49-60 years from male teachers and teachers who are aged 48 years and below. In terms of education, teachers who have diploma creates an atmosphere of cooperation rather than undergraduate teachers in stratum 1. Similarly, teachers who have tenure over 21 years are higher when establishing cooperation, compared with teachers who have tenure of under 20 years. Difference in mean scores can be said to be meaningful, because the range between 0.09 and 0.17 . and mean scores obtained by the teachers in terms of gender, age, education and length of service are still at high level.

\section{Work Motivation}

According to the respondents as a whole, it appears teachers have high work motivation in terms of gender, age and education from their period of service, because teachers have high ability and skills, working hard to achieve higher performance, aspiring high, wanting recognition and high esteem, and the desire to be an expert in this field work. This means that teachers are aware that the task as a teacher is a noble job and give their full devotion. On the other hand, from the mean score calculation based on the total sample of 312 people, data shows that the level of work motivation is at mean score of 4.15.

However, if viewed in detail it was found that men had higher scores on work motivation than female teachers, and teachers aged 49-60 years were found to have higher scores than teachers aged 48 years and below. In terms of education, teachers with degree education in stratum 1 have higher work motivation than diploma teachers. Similarly, work motivation of teachers who have tenure of more than 21 years have higher work motivation, compare to teachers of over a period of service under 20 years. Difference in mean scores can be said to be meaningful, because the range between 0.02 and 0.04 and mean scores obtained by the teachers in terms of gender, age, education and services are at high level.

\section{Initiating Structure Oriented Leadership Styles}

It was found that overall evaluation of teachers gave good answers in response in terms of gender, age, education and their period of service with the principal practising initiating structure-oriented leadership style. This is because principals scored very high in providing direction and ideas to teachers, determining the schedule teacher's job were also quite high, oversight and conduct were also evaluated based on work and they scored at high level and they also scored high enough in giving priority to goals that achieved high yields. Also, from the mean score based on the total sample of 309, data shows that the principals who practised initiating structure-oriented leadership style were at mean score of 3.79. This means that most principals practice the initiating structure-oriented leadership style on all the teachers.

However, if viewed in detail it was found that female teachers higher scored higher than men, and teachers aged 25-36 years had higher scores than teachers aged over 36 years. 
In terms of education, diploma teachers score higher than degree teachers on the initiating structure-oriented leadership style in stratum 1 . Similarly, evaluation of teachers who have a tenure of 0-10 years scored higher on initiating structure-oriented leadership style, as opposed to teachers who served a period of over 11 years. Difference in mean scores can be said to be meaningful, because the range between 0.03 and 0.15 and mean scores obtained by the teachers in terms of gender, age, education and services are at high level.

\section{Consideration Oriented Leadership Styles}

It was found that overall evaluation of teachers according to the answers by the respondents in terms of gender, age, education and period of service with the principal practising consideration-oriented leadership style (consideration) was good enough, this was because the principal is very high in establishing cooperation, creating a high atmosphere of mutual trust and respect, enforcing discipline, even involving teachers in decision-making scored high enough. They also scored high on attracting sympathetic attention to the needs of teachers and they also scored high enough in terms responsibility, ability and being active in carrying out their duties. Also, from the mean score based on the total sample of 312 people, data shows that the principals who practised consideration-oriented leadership style is at mean score of 3.85. This means that the principals practice oriented leadership style of consideration towards all teachers.

However, if viewed in detail it was found that the assessment of female teachers scored higher than men, and teachers 37-48 years old scored higher than teachers aged 2536 years and the age of teachers $49-60$ years higher assess consideration-oriented style of leadership against teachers under 48 years of age, and evaluation of diploma teachers practised initiating structure-oriented leadership style of than degree teachers in stratum 1. Similarly, evaluation of teachers who have 0-10 years of tenure scored higher for consideration-oriented leadership style, as opposed to teachers of services period over of 11 years. Difference in mean scores can be said to be meaningful, because the range between 0.01 and 0.18 . and mean scores obtained by the teachers in terms of gender, age, education and services are at high level.

\section{Teacher Job Satisfaction}

In total, data shows that the teachers' job satisfaction is high in terms of gender, age, education and in terms of length of service, because the teachers were satisfied with the job, towards the supervisor and have a close and friendly relations with colleagues with exception for salary teachers and respondents revealed that salary remains at moderate levels. Also, from the mean score of the total sample of 312 people, data shows that the level of job satisfaction is at mean score of 3.84 .

However, if viewed in detail it was found that more female teachers had more job satisfaction than male teachers, and teachers aged 25-36 years have higher scores than teachers aged 37 years and above. In terms of education, degree teachers in stratum 1 have higher work motivation than diploma teachers. Similarly, work motivation of teachers who have tenure 11-20 years have high work motivation, as compared to teachers with a service of 0-10 years and over 21 years. Difference in mean scores can be said to be meaningful, because the range between 0.02 and 0.04 . and mean scores obtained by the teachers in terms of gender, age, education and services are at high level. 


\section{Influence of Cooperative Atmosphere, Work Motivation and Leadership Styles On Teacher Job Satisfaction}

The results showed that the combination cooperative atmosphere, work motivation, initiating structure-oriented leadership style and consideration-oriented leadership style gained R2 adjusted $=.256$, means a combination of cooperative atmosphere, work motivation, initiating structure-oriented leadership style and considerations-oriented leadership style together have a significant influence on job satisfaction and contribute as much as $25.60 \%$.

The four dependent variables with the highest influence on job satisfaction is work motivation, then followed by a cooperative atmosphere, consideration oriented leadership is in the third order in influencing job satisfaction, further include initiating structure oriented leadership style, as well the significance test or the regression test separately, work motivation is the most dominant variable significance of the relationship and its influence on job satisfaction, followed by a cooperative atmosphere, consideration oriented leadership style and further by the initiating structure oriented leadership style. Also consistent with the respondent answers that work motivation gets the highest score followed by analysis of the influence of independent variables on teacher job satisfaction, either separately or in combination.

Based on the results of regression analyses further detail which simultaneously involves 21 independent indicators variables into the regression equation (stepwise), found that five of the 21 independent indicators variables correlated and have an effect on job satisfaction. The intended indicators were first; acknowledgment and appreciation, second; pursue of higher performance, third; the ability and efficiency of work motivation variables, fourth; camaraderie from cooperative atmosphere and fifth mutual trust and appreciation of the principal leadership style variables that were consideration oriented. Meanwhile indicators of the principals' initiating structure-oriented leadership style are not shown by the statistics in this study. This might be due to the all five-indicator initiating structure leadership has a weak correlation with little relevance. Statistics show that a combination of five of these indicators have adjusted $\mathrm{R} 2=.332$, meaning five of these indicators in combination immensely contributed towards the job satisfaction by a total $33.20 \%$.

Statistics show that the most powerful indicators of influence on teachers' job satisfaction is the recognition of the independent variable indicators of work motivation. This indicator contributes $20.50 \%$ on job satisfaction. The second most influential indicator of teachers' job satisfaction is the closeness of the independent variables of cooperative atmosphere, accounting for $7.90 \%$ of work satisfaction. Further indicators of an atmosphere of trust and respect from the independent variable were the principal's considerationoriented leadership style, and the ability and skills as well as the pursuit of higher performance as well as independent variables of work motivation, appear as indicators that contribute to job satisfaction. The three of these indicators contribute to teachers' work satisfaction of $2.80 \%, 1.30 \%$ and $0.70 \%$.

\section{Model Construction of Influence on Job Satisfaction}

Based on the findings as described, a model of influence on job satisfaction could be built. Construction of this model is done are using Partial Least Square (PLS). PLS is a secondgeneration approach is very moderate for structural equation modelling. Although not as popular Linear PLS Structural Relationship (LISREL) or Structural Equations (EQS), but this approach has its own advantages (Chin, 1998) and is an effective approach. This is because 
this approach requires only a minimum measure of skill requirements and the relatively small sample size (Wold, 1985).

PLS has been used in a variety of disciplines such as collaborative study (Fornell et al., 2006), global strategy (Delious \& Beamish, 1999) and research in the field of intellectual capital (Bontis et al., 2000). Next in the application of the procedure in the field, the PLS approach was computerized in the computer software package known as PLSGRAPH.

For the purpose of analysis of in this study, PLSGRAPH Version 2 software will be used. This software is used to set the t-value the significance of variables influences of the value of the critical value of 0.05 significant at $t=1.96$ with a value of more than $120 \mathrm{dk}$. Results of the analysis of this software then obtained the following relationship:

0.571

$\left(13.823^{*}\right)$

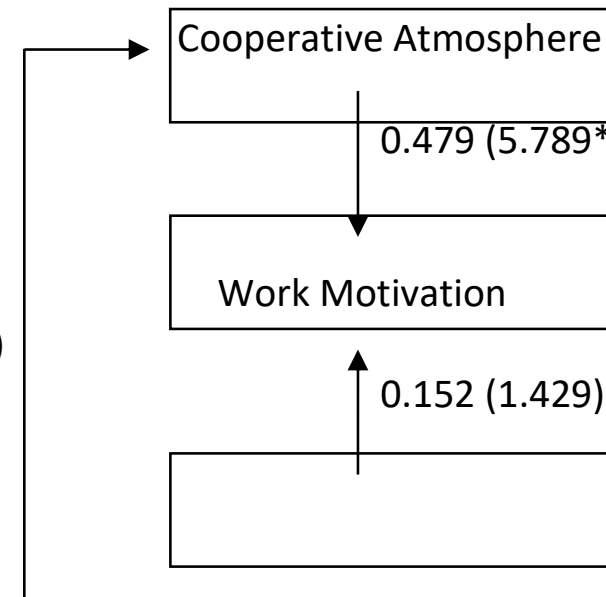

Leadership Style

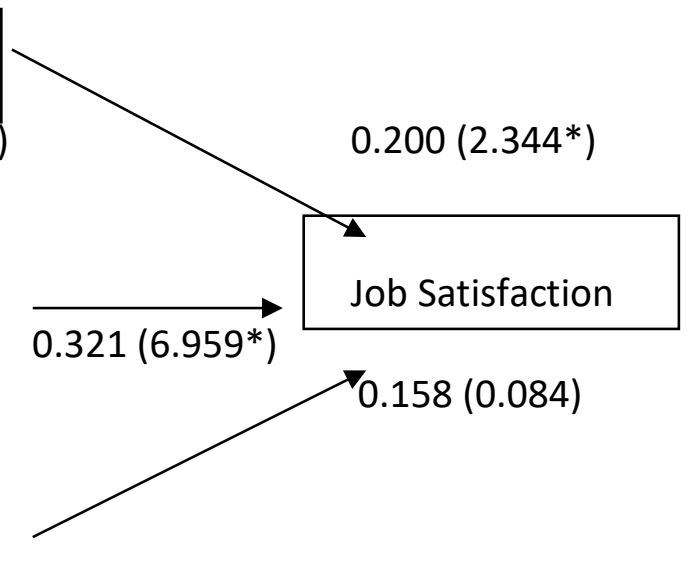

* Significance at 0.05 (critical value $\mathrm{t}=1.96$ )

Figure 1. Influence of Cooperative Atmosphere Model, Work Motivation and Leadership Styles on Teacher Job Satisfaction

From the figure, it is found that the statistical work motivation with the coefficient of 0.321 and $t=6.595$ have influence on job satisfaction. Meanwhile, with the cooperation atmosphere coefficient of 0.200 and $t=2.344$ also has an influence on job satisfaction. In addition, it was also found that the cooperation atmosphere coefficient of 0.479 and $t=5.789$ has a great influence on work motivation. This means that the cooperation atmosphere has a direct influence on job satisfaction and have an indirect influence through work motivation. Next judgment leadership style with the coefficient of 0.152 and $r=1.429$ does not have an influence on work motivation. Similarly, leadership style has no effect on work motivation (value coefficient 0158: $t=0.084$ ). However, leadership style has significant influence on job satisfaction through its influence on climate cooperation ( 0.571 coefficient value: $t=13.823$ ).

Results of the analysis also shows that the values of $\mathrm{R}$ squared to reflect the influence of cooperative atmosphere, work motivation and leadership style on job satisfaction accounted for $33.6 \%$.

\section{Conclusion}

This study was carried out to examine the relationship / influence climate of cooperation, work motivation, initiating structure-oriented leadership style and consideration-oriented leadership style (consideration) on teacher job satisfaction. Based on the findings and the 
discussion above, this study finds cooperative atmosphere, work motivation, initiating structure-oriented leadership style and consideration-oriented leadership style (consideration) are four independent variables identified to influence, contribute and determine and improve the level of teachers' job satisfaction whether separately even in combination.

\section{References}

Andrews, R. L., \& Morefield, J. (1991). Effective leadership for effective urban Schools. Educational and Urban Society, 23(3), 270-278.

Ba'ada, A. (2001). Komunikasi dalam kepemimpinan pengetua dan Kesannya kepadakepuasan kerja guru. (Unpublished doctoral dissertation). Universiti Kebangsaan Malaysia, Bangi, Malaysia.

Bontis, N., Chua, W., \& Richardson, S. (2000). Intellectual capital and business performance in Malaysian industries. Journal of Intellectual Capital.

Chin, W. W. (1998). The partial least squares approach to structural equation modelling. In G. A.Marcoulides (Ed.), Modern methods for business research (pp. 295-336). Mahwah, NJ: Lawrence Erlbaum.

Cook, J. D., Hepworth, S. J., Wall, T. D., \& Warr, P. B. (1981). The Experience of Work. A compendious and review of 242 measures and their use. London: Academic Press, Inc.

Delious, A., \& Beamish, P. W. (1999). Ownership Strategy of Japanese Firms: Transactional, Institutional and Experience Influences. Strategic Management Journal, 20(10).

Fornell, C., Mithas, S., Morgeson, F. V., \& Krishnan, M. S. (2006). Customer Satisfaction and Stock

Prices: High Returns, Low Risk. Journal of Marketing, 70(1).

Hackman J.R., \& Oldham, G.R. (1975). Development of the job diagnostic survey. Journal of Applied

Psychology, 60, 159-170.

Hair, J. F., Black, W. C., Babin, B. J., Anderson, R. E., \& Tatham, R. L. (2006). Mutivariate Data Analysis. New Jersey: Pearson Prentice Hall.

Hisham, N. B. (2014). Hubungan antara gaya kepimpinan Pengetua dengan motivasi dalam

kalangan guru Sekolah Menengah Kebangsaan Harian Daerah Kluang Johor. (Unpublished Master's thesis). UTM.

Jennifer, M. G., \& Gareth, R. J. (1999). Understanding and managing organizational behavior. Addison Wesley.

Kim, N. I. L. (1986). Relationship between principal leadership behavior and teacher stress, satisfaction and performance in the school of Incheon, Korea. Dissertation Abstract International, 47(06A).

Konting, M. M. (2000). Kaedah Penyelidikan Pendidikan. Kuala Lumpur: Dewan Bahasa dan Pustaka.

Likert, R. (1961). New patterns of management. New York: McGraw-Hill Book Co, Inc.

Locke, E. A. (1976). The nature and cause of job satisfaction. Maryland University Press.

Locke, E. A., \& Latham, G. P. (1990). Work motivation and satisfaction: Light at the end of the tunnel. Psychological Science, 1(4), 240-246.

Maslow, A. H. (1987). Motivation and personality (3rd ed.). New York: Harper and Row Publisher, Inc.

Mehrabian, A., \& Bank, L. (1978). A questionnaire measure of individual differences in ache tendency. Educational and psychological measurement, 38, 475-478. 
Mulyasa, E. (2002). Manajemen berbasis sekolah. Bandung, Indonesia: PT Remaja Rosdakarya.

Pedhazur, E. (1982). Multiple Regression in Behavioral Research: Explanation and Prediction (2nd ed.). Fort Worth, TX: Harcourt Brace College Publishers.

Sin, I. (2001). Pengaruh kepimpinan pengajaran, kepimpinan Transformasi, dan gentian kepada kepimpinan ke atas komitmen terhadap organisasi, efikasi dan kepuasan kerja guru. (Unpublished doctoral dissertation). Universiti Kebangsaan Malaysia, Bangi, Malaysia.

Smith, P. L., Kendall, L. M., \& Hulin, C. C. (1975). The measurement of satisfaction in work the retirement: A strategy for the study of attitudes. Tand McNally Company: Chicago Illinois.

Sudman, S., \& Bradburn, N. M. (1973), Asking Questions.

Vroom, V. H. (1964). Work and motivation. New York: Wiley and Sonns.

Waller, W. (1965). The sociology of teaching. New York: John Wiley \& Sons.

Warr, P., Cook, J., \& Wall, T. (1978). Scales of the measurement of some work attitudes and aspects of psychological well-being. Occupational and Organizational Psychology. The British Psychological Society.

Winardi. (1989). Strategi pemasaran. Bandung, Indonesia: Mandar Maju.

Wold, H. (1985). Partial Least Squares. In S. Kotz \& N. L. Johnson (Eds.), Encyclopedia of Statistical

Sciences (pp. 581-591). New York: John Wiley.

Yeager, S. J. (1981). Dimensionality of the job descriptive index. Academy of Management Journal, 24, 205-212. 